\title{
PEGANOL - A NEW ALKALOID FROM Peganum harmala
}

\section{V. Telezhenetskaya, Kh. N. Khashimov,}

and S. Yu. Yunusov

UDC $547.944 / 945$

Continuing the separation of the mixture of bases isolated from Peganum harmala at the flowering and

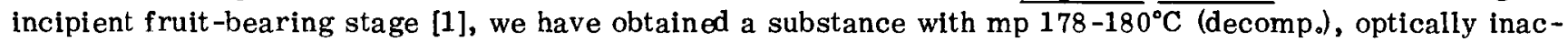
tive (nitrate with $\mathrm{mp} 137-138^{\circ} \mathrm{C}$ ), with the composition $\mathrm{C}_{11} \mathrm{H}_{12} \mathrm{~N}_{2} \mathrm{O}$, mol. wt. 188 (mass spectrometry). It proved to be a new base, and we have called peganol. Peganol is isomeric with peganine. The UV spectrum of the former possesses only one maximum, at $275 \mathrm{~nm}(\log \varepsilon$ 3.96) which shows the absence from it of a quinazolone structure [2]. This is confirmed by the IR spectrum, which has no absorption band of a carbonyl group.

We assum ed that peganine and peganol have the same heterocyclic skeleton and that the alkaloids are isomers with respect to the position of the hydroxy group. Since in the mass spectrum of peganol the main peak is that of the ion with $\mathrm{m} / \mathrm{e} 171(\mathrm{M}-17)$, the hydroxy group must be present at $\mathrm{C}-4$ or $\mathrm{C}-11$. The choice belween them was made on the basis of the NMR spectrum, which lacked a sharp two-proton singlet in the 4.5-4.6 ppm region ( $\delta$ scale) [3]. Consequently the substituent is located at $\mathrm{C}-4$, and the structure of peganol is expressed by formula (I).

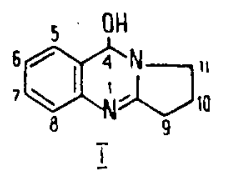

Peganol was oxidized by potassium permanganate in acetone solution. From the reaction products an individual substance was isolated, all the propertles of which coincided with those of deoxyvasicinone; a mixture gave no depression of the melting point. This confirms the proposed structure of peganol.

\section{LITERAT URE C IT ED}

1. Kh. Khashimov, M. V. Telezhenetskaya, and S。Yu。Yunusov, Khim. Prirodn. Soedin, 5, 456 (1969).

2. Kh. Khashimov, M. V. Telezhenetskaya, and S.Yu。Yunusov, Khim. Prirodn. Soedin., 6 , 453 (1970).

3. R. R. Arndt, S. H. Eggers, and A. Jordaan, Tetrahedron, 23, 3521 (1967).

Institute of the Chemistry of Plant Substances, Academy of Sciences of the Uzbek SSR. Translated from Khimiya Prirodnykh Soedinenii, No.6, pp. 849-850, November-December, 1971. Original article submitted June 25, 1971 。

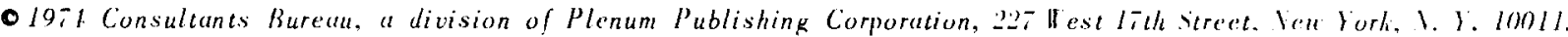
Vo part of this publication may be reproduced, stored in a retrieval system, or transmitted, in any form or by any means, clectronic, mechanical, photocopying, microfilming, recording or otheruise, without uritten permission of the publisher. 1 cops of this article is availuble from the publisher for $\$ 1.5 .00$. 